\title{
Filsafat Manusia Dan Implikasinya Terhadap Rumusan Pendidikan Islam
}

\author{
Abdul Mukit \\ STIBA Darul Ulum Banyuanyar \\ Mukitridwan28@gmail.com
}

\begin{abstract}
Sebagaimana diketahui bahwa manusia adalah makhluk spesial dan karya terbaik Allah SWT. Dalam Al-Qur'an di sebut "ahsan taqwim". Disebut karya terbaik tentu karena terdapat beberapa keistimewaan dan kelebihan yang dimilikinya. Sejak ratusan abad yang lalu, banyak filsafat yang membicarakan dan mendalami makna manusia untuk bisa menjelaskan unsur-unsur di dalamnya sehingga bisa menjelaskan dari mana dan untuk apa manusia ada. Kekeliruan dalam memahami manusia akan berdampak fata dalam merumuskan sesuatu yang terkait dengannya. Penelitian ini akan mencoba menjelaskan makna manusia dengan berbagai unsurnya dari aspek filsafat dengan bermacam alirannya. Kemudian di jelaskan keterkaitan antara filsafat manusia dengan pendidikan dan bagaimana merumuskan pendidikan Islam berbasis filsafat manusia.

As it is known that man is the special creature and the best work of God SWT. In this Qur'an called 'ahsan taqwim' It's called the best work of course because there are some privileges and advantages it has. Since hundreds of centuries ago, many philosophers have spoken and experienced human meaning to be able to explain the elements in it so that they can explain where and for what human beings are. Misconception of man will have fatal consequences in destroying something related to him. This study will try to explain the meaning of humans with its various elements from a philosophical point of view by its various streams. Then the link between the human philosophy and education and how Islam destroys the human philosophy.
\end{abstract}

Keywords: the human philosophy, Islamic Education, Implication 


\section{Pendahuluan}

Manusia sebagai makhluk Tuhan yang istimewa, menempati posisi khusus dalam setiap ideologi dan dimensi. Tidak hanya dalam dunia pendidikan, bahkan dalam seluruh ranah keilmuan seperti sosial, psikologi, politik dan sebagainya. Dalam pendidikan, pembahasan manusia adalah pintu pertama untuk bisa merumuskan komponen pendidikan lainnya seperti, visi dan misi, tujuan, kurikulum, metodologi, guru dan sebagainya. Karena hal tersebut, baru dapat di rumuskan dengan benar, jika objek pendidikan berupa manusia dikenali dan dipahami dengan benar. Pendidikan yang di dambakan adalah untuk manusia. Manusia adalah poros utama pendidikan, maka menjadi keharusan bagi setiap filsafat pendidikan untuk dapat menjelaskan hakikat manusia seutuhnya. Kesalahan dalam memahami hakikat peserta didik akan menjadikan kegagalan dalam proses pendidikan. ${ }^{1}$

Lebih lanjut dijelaskan paling tidak ada enam landasan dasar mengenai ikatan dan kaitan antara memahami dan mendalami filsafat manusia dengan pendidikan:

Pertama, objek pendidikan adalah manusia, baik sebagai pendidik maupun peserta didik. Manusia sebagai pendidik atau peserta didik merupakan inti dan poros dari pendidikan yang harus diketahui dengan jelas dan benar. Kedua, pemikiran tentang manusia adalah titik tolak perumusan komponen pendidikan lainnya meliputi; visi, misi, tujuan, kurikulum, pendidik, peserta didik, proses belajar mengajar, kepemimpinan, pengelolaan dan lingkungan. Pengetahuan mengenai manusia yang seutuhnya akan mampu merumuskan pendidikan yang benar-benar dibutuhkannya. Tanpa pengetahuan tersebut bisa dipastikan, pendidikan tidak akan dapat menjalankan fungsi dan tuganya. Ketiga, kajian tentang manusia telah melahirkan berbagai konsep termasuk konsep pendidikan Islam. Konsep adalah rancangan ide yang dirumuskan berdasarkan identifikasi objek penelitian. Konsep akan sangat membantu terciptanya proses pendidikan yang

\footnotetext{
${ }^{1}$ Abdul Majid dan Jusuf Mudzakkir, Ilmu Pendidikan Islam, Jakarta: Kencana, 2008, hlm. 104
} 
lancar sesuai dengan keinginan dan kebutuhan. Keempat, filsafat tentang manusia akan dapat merumuskan filsafat pendidikan yang benar. Itu disebabkan karena filsafat pendidikan didasarkan kepada pengetahuan yang utuh mengenai manusia. Kelima, filsafat akan memberikan solusi berbagai persoalan dan masalah. Karena filsafat membicarakan persolan secara mendasar (hakikat/essence), maka solusi yang diberikan juga akan berdampak mendasar. Keenam, filsafat manusia akan dapat menjawab beberapa pertanyaan seperti, mengapa manusia perlu di berikan pendidikan? Apakah manusia dapat diberikan pendidikan? Pendidikan yang bagaimana yang diperlukan manusia? Bagaimana cara mendidik manusia dan pertanyaan lainnya. ${ }^{2}$

Artikel ini akan membahas filsafat manusia yang dibagi dalam beberapa pembahasan. Pembahasan pertama mengenai manusia dalam pandangan Barat. Pembahasan kedua mengenai manusia dalam Islam. Pembahasan ketiga mengenai hubungan filsafat manusia dengan perumusan konsep pendidikan.

\section{Metode Penelitian}

Metode penelitian ialah cara kerja meneliti, mengkaji dan menganalisis objek sasaran penelitian untuk mencari hasil atau kesimpulan tertentu.

Karena penelitian ini bersifat studi teks, maka salah satu cara adalah survei literature yaitu mencari dan mempelajai bahan-bahan tertulis yang berkaitan dengan ob jek kajian teks tersebut.

Penulis uraikan sebagai berikut;

\section{Jenis Penelitian}

Penelitian ini berjenis kualitatatif, yaitu dengan penelitian pustaka (library research), yakni dengan menelusuri data pustaka yang ada dalam buku serta melengkapinya dengan pustaka lain yang berhubungan dengan kajian tersebut. Penelitian ini dilakukan dengan membaca, menelaah, dan menganalisis content buku dan didukung berbagai literatur yang berhubungan dengannnya.

\footnotetext{
${ }^{2}$ Abudin Nata, Pemikiran Pendidikan Islam dan Barat, Jakarta: PT Grafindo Persada, 2012, cet ke.I, hlm.63-65
} 


\section{Sifat Penelitian}

Penelitian ini bersifat deskriptif-analitik, yakni penelitian yang berfungsi untuk menyelesaikan masalah melalui pengumpulan, penyusunan, dan proses analisa mendalam terhadap data yang ada untuk kemudian dijelaskan dan selanjutnya diberi penilaian. ${ }^{3}$

\section{Sumber Data}

Data yang digunakan dalam penelitian ini diambil dengan menelusuri, mengumpulkan, dan meneliti berbagai referensi yang berkaitan dengan dengan tema yang diangkat. Sumber data dalam penelitian pustaka ini dibagi menjadi dua, yakni data primer dan data sekunder.

\section{a. Data Primer}

Dalam penelitian ini, yang menjadi data primer adalah buku AlButhi "Kubrâ Al-Yaqiniyyât Al-Kauniyah; Wujûd Al-Khâliq wa Wadzifât Al-Maklûq"cetakan (Damaskus, Darul Fikr, 1997), Abudin Nata, Pemikiran Pendidikan Islam dan Barat, Jakarta: PT Grafindo Persada, 2012; Ahmad Tafsir, Filsafat Pendidikan Islam, Bandung: Rosdakarya, 2000; Dan Ahmad Tafsir , Ilmu Pendidikan Islami, Bandung: Rosdakarya, 2000

\section{b. Data Sekunder}

Data sekunder adalah semua data yang berhubungan dengan objek kajian, baik berupa buku, jurnal, artikel-artikel yang tersebar di situssitus internet, dan data lain yang relevan dengan kajian penelitian ini. Seperti buku, Majid 'Irsan Al-Kîlanî, Al-Fikr Al-Tarbawi 'Inda Ibn Taimiyah, Madinah Munawarah: Maktabah Dar al-Turats, 1986 M/ 1407 H; Khâlid bin Hâmid Al-Hâzimî, Ushul al-Tarbiyah al-Islamiyah, Riyadl: Dar 'Alam Al-Kutub, 2000; Abdurrahman Al-Nahlawî, Ushul Al-Tarbiyah Wa Asalîbuha fi Al-Baiti Wa Al-Madrasah Wa AlMujtama', Damaskus: Dar Al-fikr, 2008 M/ 1429 H; Hasan Ibrahim

\footnotetext{
${ }^{3}$ Rianto Adi, Metodologi Penelitian Sosial dan Hukum, Jakarta: Granit, 2004, hlm. 128.
} 
Abdul 'Al, Al-Muqaddimah fi Al-Falsafah Al-Tarbiyah Al-Islamiyah, Riyadl: Dar 'Alam al-Kutub, 1985; Muhammad Al-Ghazâlî, 'Aqidatu Al-Muslim, Mesir: Dar Nahdlah Mishr, 2005; Omar Muhammad AlSyaibanî, Filsafat Pendidikan Islam, Jakarta: Bulan Bintang, tnp. thun; Abdul Majid dan Jusuf Mudzakkir, Ilmu Pendidikan Islam, Jakarta: Kencana, 2008; Abudin Nata, Pemikiran Pendidikan Islam dan Barat, Jakarta: PT Grafindo Persada, 2012; Quraish Shihab, Wawasan AlQur'an, Bandung: Penerbit Mizan, cetakan VII, 1996; Tim Lokakarya, Islam dan Pendidikan Nasional, Jakarta: Lembaga Penelitian IAIN Syarif Hidayatullah, 1983; Wan Mohd Noor Wan Daud, Filsafat dan Praktik Pendidikan Islam Menurut Syed Naquib Al-Attas, Bandung: Mizan, cet ke-I, 2003

\section{Pembahasan}

\section{Manusia di Barat}

Para pakar berbeda pandangan dalam menjelaskan manusia di sebabkan perbedaan perspektif masing-masing pemikir. Ada yang berpendapat manusia hanya sekumpulan materi yang tersusun dari benda-benda kimia. Pendapat lain menjelaskan bahwa ia tersusun dari jasad dan akal dengan akal sebagai controle dan inti dari setiap perilakunya. Bagi pendapat pertama bahwa semua kegiatan yang dilakukan manusia mulai dari berpikir, merasa, merenung, mencipta, mengingat dan lainnya, tiada lain hanya sebatas kecenderungan psikologi saja yang sebenarnya semua itu adalah bangunan dari materi. Pendapat ini melihat manusia adalah sekumpulan materi yang terdiri dari bentuk, ukuran, warna. Singkatnya ia hanyalah daging dan tulang yang butuh makan dan minum, tempat dan waktu untuk tinggal. Ia adalah makhluk fisik (lawan dari metafisik) yang harus diberlakukan baginya aturan-aturan fisika. Pendapat ini sebenarnya bukan hal yang baru. Jauh sebelumnya Filsofof 
Yunani, Democrates dan al-Rawaqiyyin yang dilajutkan pada masa berikutnya oleh para pakar ilmu jiwa yang di pelopori oleh Watson. ${ }^{4}$

Begitu juga pendapat kedua yang menekankan aspek rasional dalam diri manusia. Dengan berbagai versi dan penekan pada unsur tertentu dari manusia, pandangan ini pada hakikatnya menolak jika manusia hanya disebut makhluk materi belaka. Di mulai oleh Socrates (470-399 SM) yang mengungkapan hakikat manusia ada pada keingintahuannya untuk itu ia membutuhkan seseorang agar memberitahunya. Plato (w. 347 SM) menurutnya jiwa adalah entitas non material yang dapat terpisah dari tubuh, menurutnya jiwa tersebut ada sebelum kelahirannya dan oleh karena itu ia akan abadi selamanya. Menurut Plato jiwa manusia memiliki tiga elemen, roh, rasio, dan nafsu.

Berdasarkan ini Plato membagi manusia menjadi tiga kelompok:

Pertama, manusia yang di dominasi oleh rasio yang ingin meraih pengetahuan. Kedua, manusia yang didominasi oleh roh yang ingin meraih reputasi. Ketiga, manusia yang didominasi oleh nafsu yang ingin meraih materi. Rene Descartes (1596-1650), juga menekankan rasio yang membedakannya dengan tingkah laku hewan yang bersifat mekanis. Ciri rasionya adalah bebas memilih. Jhon Locke (1623-1704), yang terkenal lewat teori tabula rasa mengatakan jiwa manusia saat dilahirkan laksana kertas putih, kemudian di isi oleh pengalaman-pengalaman. Immanuel Kant (1724-1804), filsafat rasional yang mengatakan manusia bebas bertindak berdasarkan alasan moral bukan hanya untuk kepentingan sendiri. ${ }^{5}$

Tampaknya perbedaan yang dianut oleh para pakar, kembali kepada perspektif masing-masing disiplin ilmu yang mempunyai pengertiannya dan membatasi dirinya sendiri. Cara pandang seperti ini bersifat parsial yang tidak dapat melihat persoalan secara menyeluruh. Berikut akan di uraikan lebih lanjut:

\footnotetext{
${ }^{4}$ Hasan Ibrahim Abdul 'Al, Muqaddimah fi Falsafah al-Tarbiyah al-Islamiyah, Riyadl: Dar 'Alam al-Kutub, 1985, hlm.21

${ }^{5}$ Ahmad Tafsir, Filsafat Pendidikan Islam, Bandung: Rosdakarya, 2008, hlm.08-13
} 


\section{a. Menurut Ilmu Antropologi}

Melihat manusia berdasarkan teori evolusi yang berpendapat, manusia muncul dari suatu sel yang sangat sederhana kemudian berproses secara bertahap menuju taraf yang lebih sempurna dan dalam proses tersebut terdapat hukum berjuang dan bertahan hidup. Asal usul manusia berasal dari benda yang tidak bernyawa dengan sel yang sangat sederhana (anorganisme), kemudian berubah menjadi tumbuh-tumbuhan (vegetatif) selanjutnya menjadi binatang (sensitifa), makhluk yang mendekati manusia (homo sapiens), makhluk purbakala primitif, dan menjadi manusia seperti sekarang.

\section{b. Menurut Sosiologi}

Adalah makhluk yang hidup berkelompok. Sejalan dengan pendapat Aristoteles manusia adalah zoon politkon. Pandangan ini melihat manusia sebagai makhluk sosial yang terikat dengan orang lain. Ia tidak bisa hidup sendiri dan sangat bergantung kepada bantuan orang lain. Pandangan merupakan anti tesis dari paham individualisme yang menempatkan manusia terpisah dari lainnya.

\section{c. Menurut Psikologi}

Pertama, teori disiplin mental yang menyatakan bahwa sejak kelahirannya manusia mempunyai potensi bawaan yang dikembangkan melalui proses belajar. Potensi tersebut berupa daya (theistik), daya yang menekankan keutuhan dan keseluruhan (humanistik), bukan hanya kemampuan namun juga kemamuan dan kesanggupan untuk berkembang (naturalistik) dan apersepsi (herbart), yang menghasilkan nativisme (Arthur Schopenhauer).

Kedua, teori behaviorisme berpendapat manusia tidak membawa potensi apa-apa sejak lahir. Perkembangannya dibentuk oleh faktor-faktor seperti lingkungan dll, baik sebagai ketundukan terhadap hukum stimulus (stimulus respon) dengan tokoh utamanya Edward L. Thorndike yang mengemukakan hukum belajar yang sangat terkenal: law of readness (kesiapan), law of exercise or repition (pengulangan) dan law of effect (pengaruh). Aliran 
kedua dari behaviorisme adalah conditioning, pembentukan stimulus dan respon perlu dibantu dengan kondisi tertentu dengan tokoh utamanya adalah Watson. Teori ketiga, adalah reinforcement tokoh utamanya C.L. Hull, yaitu pengembangan dari SR, yaitu menempatkan kondisi diberikan pada respon. Kemudian teori behaviorisme dikembangkan oleh Jhon Locke yang membentuk aliran empirisme dengan teori tabula rasa, mengajar seperti mengisi air ke dalam gelas, menggoreskan sesuatu pada kertas, manusia dalam teori ini ditempatkan sebagai robot.

Ketiga, teori Cognitive Gestalt Field. Belajar adalah proses pengembangan insigh pegubahan pemahaman lama.

Keempat, teori konvergensi yang dikembangkan oleh William Stern, yang menyatakan pembentukan kepribadian bukan hanya ditentukan oleh faktor diatas namun juga oleh lingkungan.

\section{d. Menurut para filsuf}

Adalah makhluk yang mempunyai cita, rasa dan karsa, ia berpengetahuan dan berpendidikan. Memiliki daya pikir (nathiqah) yang terdiri dari akal praktis (amali) dan teoritis (nadzari). Mempunyai beberapa tingkatan: 1. akal huyulani, yang belum dilatih seperti akal anak-anak. 2. Akal aktual (bil fi'li) dapat melepaskan arti dari materinya, telah mempunyai wujud dalam akal. 3. Akal mustafad yang dapat menangkap bentuk semata-mata atau dapat menagkap maksud abstrak yang dapat menerima pengetahuan dari akal aktif $\left(\right.$ aql fa'al). ${ }^{6}$

Dari beberapa pandangan di atas dapat disimpulkan bahwa manusia dalam pandangan pemikir Barat bergantung dari paradigma masing-masing pakar. Karena manusia dalam terminologi psikolog tidak sama dengan terminologi sosiolog maupun filosof. Lebih dari itu perbedaan tersebut bukan hanya dalam ranah syakli (kulit luar) namun juga pada esensi (hakikat) manusia. Terlihat jelas mulai dari yang memaknai manusia hanya sebatas materi, berunsurkan daging dan tulang, tidak ubahnya seperti robot, atau ia

\footnotetext{
${ }^{6}$ Abudin Nata, Pemikiran Pendidikan Islam dan Barat, hlm. 65-76
} 
adalah makhluk yang juga berunsurkan akal. Aliran filsafat materialisme, empirisme, rasionalisme, maupun spritualisme, masing-masing menekankan maksudnya yang berbeda dari yang lain. Hal itu disebabkan karena pengetahuan Barat didasarkan kepada daya nalar (ratio) dan hal lain yang bersifat experimental (tajribi) sehingga menjadikan pemahaman mengenai manusia tidak sejajar dan berdampak parsial. Jikapun ada aliran yang berusaha menjembatani problem dikotomis tersebut seperti teori konvergensi atau mungkin yang dikenal sekarang dengan ESQ (emotional, spiritual, question) namun tetap saja terdapat missing link, mata rantai yang hilang dengan sang Pencipta Yang Maha Tahu (aql fa'al) mengenai makhluknya bernama manusia tersebut.

\section{Manusia dalam Islam}

Harus diyakini bahwa sebagai agama yang paripurna, Islam menganut sistem yang sempurna. Semua persoalan apapun yang dihadapi oleh setiap muslim harus "dikembalikan” kepada Al-Qur'an dan tuntunan Nabi (sunah). Dalam kaitannya dengan manusia sebagai objek pendidikan, pendidikan Islam tidak mau berapologi, mencoba-mencoba atau mengikuti prasangka (dzan) dan khayalan (wahm). Manusia dalam Islam adalah makhluk yang dijelaskan oleh Tuhan sebagai Pencipta Yang Maha Mengetahui ciptaan-Nya.

Manusia disisi Allah adalah sebagai salah satu ciptaan (makhluk) Allah. Sebagaimana dalam QS. 96 : 2“Dia telah menciptakan manusia dari segumpal darah." QS. 2 : 21“Hai manusia, sembahlah Tuhanmu Yang telah menciptakanmu dan orang-orang yang sebelummu, agar kamu bertakwa." Jadi manusia datang dan berasal dari Allah.

Allah swt memberikan keutamaan lebih kepada manusia dari pada makhluk yang lain. Manusia dilantik menjadi Abdullah dan Khalifatullah dimuka bumi ini untuk memakmurkannya. Oleh karena itu dibebankan kepada manusia amanah taklif, dan diberikankan pula kebebasan dan tanggung jawab memiliki serta memelihara nilai-nilai kemuliaan. Kemuliaan yang diberikan bukanlah karena bangsanya, warna kulitnya, kecantikannya, perawakannya, 
harta, derajatnya, akan tetapi semata-mata karena iman dan dan taqwanya kepada Allah swt.

Semua itu dijelaskan dalam al-qur'an surat al-baqarah ayat 21

Hai manusia, sembahlah Tuhanmu yang Telah menciptakanmu dan orang-orang yang sebelummu, agar kamu bertakwa,

Allah swt juga menjelaskan hakikat ciptaan manusia dalam surat AzZariyat ayat 56 yang artinya "Aku tidak menciptakan jin dan manusia melainkan agar mereka beribadah kepada-Ku"

Hakikat manusia menurut Al-Qur'an ialah bahwa manusia itu terdiri dari unsur jasmani, unsur akal, dan unsur ruhani. Ketiga unsur tersebut sama pentingnya untuk di kembangkan. Sehingga konsekuensinya pendidikan harus di desain untuk mengembangkan jasmani, akal, dan ruhani manusia.

Unsur jasmani merupakan salah satu esensi ( hakikat ) manusia sebagai mana dijelaskan dalam Al-Qur'an surat al-baqarah ayat 168 yang artinya " Hai sekalian manusia makanlah yang halal lagi baik dari apa yang terdapat dari bumi, dan janganlah kamu mengikuti langkah-langkah syetan karena sesungguhnya syuetan itu adalah musuh yang nyata bagimu "

Akal adalah salah satu aspek terpenting dalam hakikat manusia. Akal digunakan untuk berpikir, sehingga hakikat dari manusia itu sendiri adalah ia mempunyai rasa ingin, mempunyai rasa mampu, dan mempunyai daya piker untuk mengetahui apa yang ada di dunia ini.

Sedangkan aspek ruhani manusia di jelaskan dalam al-Qur'an surat AlHijr ayat 29 yang artinya " Tatkala aku telah menyempurnakan kejadiannya, aku tiupkan kedalamnya ruhku.kedalamnya, maka tunduklah kamu kepadanya dengan bersujud".

Memang dalam prosesnya, penciptaan manusia berevolosi (QS Al-Hajj, 22;5), berasal dari air mani, berubah menjadi segumpal darah (mudghah), daging ('alaqah), tulang, dan dibungkus dengan daging (lahm). Namun evolusi yang sangat berbeda dengan teori evolusi Barat yang menganggap manusia berasal dari materi yang tidak bernyawa, kemudian menjadi sejenis hewan, manusia 
purba, manusia seperti sekarang dan selanjutnya akan terus berkembang dipengaruhi oleh seleksi alam. Manusia adalah makhluk sosial yang seimbang (QS Al-Hujurat, 49: 13) dan (QS Al-Maidah, 5: 2), bukan hanya mementingkan dimensi sosial sehingga melupakan keperluan dan kebutuhan pribadi (individu) namun seimbang antara dia sebagai abdullah, hamba yang harus patuh kepada Tuannya, dan memenuhi segala kebutuhannya pun juga sebagai khalifah di bumi yang berdimensi social. Manusia dipengaruhi oleh bakat dan kemampuan bawaan dan bentukan faktor lain seperti likungan. Berbeda dengan aliran nativisme yang hanya percaya pada bakat bawaan dan behaviorismenya Jhon Locke yang hanya mengimani eksperimental. ${ }^{7}$

Pendidikan manusia harus mengindahkan ketiga unsur: akal, jasmani dan hati nurani. ${ }^{8}$ Dari itu yang dimaksud pendidikan manusia seutuhnya adalah yang memperhatikan tiga unsur diatas. Semua unsur tidak boleh terlewatkan. Dengan pendidikan tersebut akan menghasilkan insan kamil. Islam menekankan pada keseimbangan. Tidak boleh mengabaikan salah satu dari ketiga unsur diatas, yang mengabaikan telah megabaikan manusia itu sendiri. Hal itu yang membuat pendidikan Islam mampu menumbuhkan dan mengembangkan potensi manusia secara keseluruhan.

Dalam Al-Qur'an, terdapat tiga istilah penting yang digunakan untuk menunjukan makna manusia: insan, bayasr, dan dzurriyati Adam.

Kata insan berasal dari akar kata uns yang berarti jinak, harmonis dan tampak. Dalam al Qur'an kata insan seringkali dihadapkan dengan kata jin/jan. Jin adalah makhluk halus yang tidak tampak, sedangkan manusia adalah makhluk yang nyata dan tampak. Dengan demikian, kata insan, digunakan al Qur'an untuk menunjuk kepada manusia dengan seluruh totalitasnya, jiwa dan raga. Manusia berbeda dengan makhluk lain dalam hal fisik, mental dan kecerdasan. Surat At Zaitun ayat 4. Penyebutan manusia dengan nas lebih

\footnotetext{
${ }^{7}$ Al-Buthi, “Kubra Al-Yaqiniyyat Al-Kauniyah: Wujûd Al-Khâliq wa Wadzifât Al-Maklûq”, 1997, hlm. 79-81.

${ }^{8}$ Tim Lokakarya, Islam dan Pendidikan Nasional, Jakarta: Lembaga Penelitian IAIN Syarif Hidayatullah, 1983, hlm.139.
} 
menonjolkan bahwa manusia merupakan makhluk sosial yang tidak dapat hidup tanpa bantuan dan bersama-sama manusia lainnya. Kata nas merupakan bentuk jamak dari kata insan yang tentau saja memiliki makna yang sama. AlQuran menyebutkan kata nas sebanyak 240 kali.

Al-Quran menginformasikan bahwa penciptaan manusia menjadi berbagai suku dan bangsa bertujuan untuk bergaul dan berhubungan antar sesamanya (ta'aruf ) (QS. al-hujurat [49]: 13), saling membantu dalam melaksanakan kebajikan (QS. al-Maidah [5]: 2), saling menasihati agar selalu dalam kebenaran dan kesabaran (QS. al-'Ashr [103]:3), dan menanamkan kesadaran bahwa kebahagiaan manusia hanya mungkin terwujud bila mereka mampu membina hubungan antar sesamanya (QS. Ali Imran [3]: 112).

Kata basyar secara etimologis berasal dari kata ( $b a^{\prime}$, syin, dan $\left.r a^{\prime}\right)$ yang berarti sesuatu yang tampak baik dan indah, bergembira, menggembirakan, menguliti/mengupas (buah), atau memperhatikan dan mengurus suatu. Kata basyar digunakan al-Quran untuk menyebut manusia dari sudut lahiriah serta persamaannya dengan manusia seluruhnya. Kata basyar juga selalu dihubungkan dengan sifat-sifat biologis manusia, seperti asalnya dari tanah, yang selanjutnya dari sperma dan berkembang menjadi manusia utuh (QS. alMu'minun [23]: 12-14), manusia makan dan minum (QS. al-Mu'minun [23]: 33; QS. al-Furqan [25]: 20), dan seterusnya. Karena itulah Nabi Muhammad saw. diperintahkan untuk menyampaikan bahwa beliau sama seperti manusia lainnya. Yang membedakannya hanyalah beliau diberi wahyu (QS. al-Kahfi [18): 110). Kata basyar ini disebutkan al-Quran sebanyak 36 kali.

Dari sisi lain, banyak ayat-ayat al Qur'an yang menggunakan kata basyaryang mengisyaratkan bahwa proses kejadian manusia sebagai basyar, melalui tahap-tahap sehingga mencapai tingkat kedewasaan. (Ar Rum:20)

Demikian terlihat basyar dikaitkan dengan kedewasaan dalam kehidupan manusia, yang menjadikannya mampu memikul tanggung jawab. Dan karena itu pula, tugas kekhalifahan dibebankan kepada basyar (Perhatikan 
Surat Al Hijr :28 menggunakan kata basyar dan Al Baqarah :30 menggunakan kata khalifah).

Dengan demikian, kata bani Adam dan dzurriyatu Adam digunakan untuk menyebut manusia dalam konteks historis. Secara historis semua manusia di dunia ini sama, yakni keturunan Adam yang lahir melalui proses secara biologis (QS. al-Sajdah [32]: 8). Kata bani Adam disebutkan al-Quran sebanyak 7 kali, di antaranya dalam surat al-A'raf (7): 26, 27, 31, dan 35. Dalam QS. alA'raf (7): $31 . .^{9}$

Seperti disebutkan sebelumnya bahwa unsur (kayan) manusia adalah jasad, akal dan wijdan. Akal adalah alat untuk mengetahui dan menyadarkan $\left(a l-w a^{\prime} y\right)$, ia mempunya pasukan untuk membantunya mewujudkan perbuatan.Sementara wijdan (rasa-emosi) disebut sebagai 'athifah yaitu kekuatan pendorong yang mempengaruhi perbuatan. Bila fungsi akal untuk menerangi jalan (idlâatan li al-thariq) dan menjelaskan kebenaran (tabshiran lil alhaqq) sedangkan wijdan berfungsi sebagai penggerak perbuatan sesuai dengan kecenderungan terhadap faktor pendorong. ${ }^{10}$ Biasanya perbuatan manusia lebih banyak di dorong oleh wijdan dibanding akal. Oleh sebab itu, dibutuhkan pendidikan integratif yang memadukan antara dua potensi kekuatan, aqliyah dan wijdaniyah secara bersamaan. ${ }^{11}$

Berdasarkan hal diatas, Al-Syabaini menegaskan beberapa prisnsip dasar pandangan Islam terhadap manusia:

Pertama, manusia adalah makhluk yang paling mulia. Disebutkan 3 kali pada surah al-'Alaq: dijadikan dari 'alaq (segumpal darah), menerangkan ciri atau dayanya untuk berpikir, mengingatkan bahwa insan cenderung bersifat congkak. Kedua, manusia dipercaya menjadi khalifah di bumi dengan kebebasan dan tanggung jawab (al-Ahzab: 72). Ketiga, manusia adalah makhluk yang berpikir yang mempunyai beberapa ciri: 1. Kemampuan berbahasa. 2.

\footnotetext{
${ }^{9}$ Quraish Shihab, Wawasan Al-Qur'an, Bandung: Penerbit Mizan, cetakan VII, 1996, hlm.279

${ }^{10}$ Al-Buthi, Al-Islâm Malâdza Kulli Al-Mujtama'ât A-Insâniyah, Limâdzâ wa Kaifa?, Damasus : Dar Al-Fikr, 1413 H/ 1993 M, hlm. 200

${ }^{11}$ Ibid, hlm. 201
} 
Kecenderungan beragama, 3. Kecenderungan moral. 4. Kecenderungan bermasyarakat. Keempat, manusia mempunyai tiga dimensi: jasad, akal dan ruh seperti segitiga. Islam tidak hanya mengakui ketiga unsur ini namun meneguhkannya. Islam menolak materialisme dan spritualisme. Kelima, manusia terpengaruh oleh lingkungan. Keenam, manusia mempunyai motivasi dan kebutuhan. Ketujuh, manusia berbeda dengan lainnya. Kedelapan, manusia mempunyai sifat yang selalu berubah. ${ }^{12}$

Dalam diri manusia terdapat potensi yang perlu didik dan dikembangkan sebagaimana tugas pendidika Islam untuk pendidikan tauhid, dan pengembangan potensi peserta didik. ${ }^{13}$ Kurang lebih ada tujuh potensi yang perlu dikembangan yaitu:

1. Fitrah (citra asli): fitrah beragama, fitrah intelek, sosial, susila, ekonomi, seni, kemajuan, keadilan, ingin dihargai, kawin, cinta tanah air, dan kebutuhan hidup lainnya. 2. Struktur manusia terdiri atas: jasmani, rohani dan nafsani: kalbu, akal dan hawa nafsu. 3. Al-hayah (vitality): jasmani dan rohani. 4. Al-khuluq (karakter). 5. Tabiat, citra batin individu yang menetap. 6. Al-Sajiyah (bakat), kapasitas, bakat yang bersifat potensial. 7. Sifat. 8. Perilaku. ${ }^{14}$

Kaitannya dengan manusia sebagai pendidik, ada pandangan yang menyatakan bahwa, pendidik dalam Islam sama dengan teori Barat yaitu orang yang bertanggung jawab terhadap perkembangan seluruh potensi peserta didiknya, baik potensi afektif (rasa), kognitif (cipta) dan psikomotorik (karsa). ${ }^{15}$ Pandangan ini tidak tepat jika kesamaan yang dimaksudkan adalah hakikat pendidik. Karena walaupun penggunaan kedua istilah diatas sama, namun berbeda maksud dan tujuan. Konsep Islam mengenai manusia sebagai pendidik di adopsi dari firman Allah Yang Maha Mengetahui, sedangkan Barat didasarkan kepada daya akal dan kemampuannya.

${ }^{12}$ Omar Muhammad Al-Syaibani, Filsafat Pendidikan Islam, Jakarta: Bulan Bintang, tnp. thun, hlm.103-156.

${ }^{13}$ Madjid Irsan Al-Kilani, al-Fikr al-tarbawi 'inda Ibn Taimiyah, Madinah Munawarah: Maktabah Dar al-Turats, hlm.91-103

${ }^{14}$ Abdul Mujib dan Jusuf Mudzakkir, Ilmu Pendidikan Islam, hlm.53-62

${ }^{15} \mathrm{Ibid}, \mathrm{hlm} .87$ 
Sedangkan manusia sebagai peserta didik dapat dijelaskan sebagai berikut:

Pertama, peserta didik bukan miniatur orang dewasa. Kedua, memiliki kebutuhan. Ketiga, memiliki perbedaan antara individu dengan lainnya. Keempat, dipandangan sebagai kesatuan sistem manusia. Kelima, subjek dan objek yang diharapkan aktif, kreatif, produktif. Keenam, mengikuti periodeperiode perkembangan tertentu. ${ }^{16}$

Kesimpulannya, bahwa Islam memandang manusia satu kesatuan yang tak terpisahkan. Ia bukan hanya jasad tanpa ruh, seperti pendapat filsafat materialisme ataupun ruh tanpa jasad seperti pandangan aliran spritulaisme. Sebagaimana ia bukan hanya akal sekedar sedang jasad hanyalah hasil dari akal (nitaj 'aql) seperti pendapat filosof yang berpandang thinking being atau yag dikenal cogito ergo sum oleh bapak Filsafat Modern. ${ }^{17}$ Islam memandang manusia seutuhnya, jasad dan ruh tak terpisah, menyatu dan seirama, akal, ruh dan jasadnya membentuk segitiga sama sisi yang harus sama-sama di isi, ia adalahh makhluk yang bersifat individu (fardiyah) sekaligus berkarakter sosial (ijtima'i), itu semua karena ia ciptaan Allah yang sempurna (ahsani taqwim).

\section{Konsep Pendidikan}

Perbedaaan landasan da pijakan pengambilan sumber pengetahuan diatas berimplikasi terhadap perbedaan penetapan konsep penting dalam pendidikan. Berikut penulis uraikan dibawah ini.

\section{Visi, Misi, Tujuan dan Hakikat Pendidikan}

Visi (What are Will becoming), misi (what are will doing), tujuan (what are to achieve: apa yang ingin dicapai), hakikat (what the essence of it: esensi masalah)??? 18 Berdasarkan landasan filosofis pandangan Islam mengenai manusia dapat dirumuskan sebuah visi bahwa pendidikan Islam ingin

\footnotetext{
${ }^{16}$ Abdul Mujib dan Jusuf Mudzakkir, Ilmu..., hlm.105-106

${ }^{17}$ Hasan Ibrahim Abdul 'Al, Muqaddimah fi Falsafah al-tarbiyah al-Islamiyah, Riyadl: Dar 'alam al-Kutub, 1958, hlm.31

${ }^{18}$ Abudin Nata, Pemkiran..., hlm.87
} 
mencetak manusia sempurna (insan kamil) sebagai hamba Allah ('abid) juga khalifah di bumi (pengelola bumi).

Sedangkan untuk dapat menggapai misi tersebut dapat dilakukan beberapa langkah misalnya: a. Mendekatkan diri kepada Allah dengan semua ritualistik ibadah. b. Mengasah dan mengembangkan potensi bawaan dengan pendidikan dan pengalaman sesuai dengan kebutuhan duniawi dengan memperhatikan berbagai aspek mulai dari jasad, ruh dan akal.

Mengenai tujuan, yaitu apa yang harus dicapai dalam pendidikan Islam meliputi: pembangunan keilmuwan, pembangunan akidah, pembinaan ibadah, pembangunan akhlak, pembinaan skill dan keterampilan dan pembinaan jasmani ${ }^{19}$ atau dalam bahasa lain untuk mewujudkan muslim yang kaffah yang meliputi;

1. Jasmaninya sehat serta kuat

2. Akalnya cerdas serta pandai

3. Dan hatinya dipenuhi iman kepada Allah. ${ }^{20}$

Pemikir Barat seperti Jhon Dewey melihat bahwa, pendidikan tidak punya tujuan secara internal yang menetapkan tujuan adalah masyarakat, orang tua dan guru. Hal ini terkait erat dengan dasar filsafat pendidikan yang dianutnya yaitu eksperimen. Walupun pengertian pengalaman menurut Dewey tidak sama dengan aliran empirisme lainnya seperti Jhon Locke. Karena Dewey masih mengakui keterlibatan rohani. Sedangkan Jhon Locke melalui teori tabula rasa-nya dan aliran empirisme lainnya sama sekali tidak mengakui adanya peran pembentuk pengetahuan selain sesuatu yang bersifat inderawi (empirisme).

Arthur Scopenhaur dengan teori nativismenya menggariskan tujuan pendidikan hanya sebagai alat yang menyesuaikan diri dengan bakat dan potensi anak. Sedangkan konvergensi William Stern berusaha mengakomodasi semua. Maka teori ini merumuskan tujuan pendidikan tidak hanya untuk

\footnotetext{
19 Al-Hazimi, Ushul al-Tarbiyah al-Islamiyah, Pustaka Dar 'alam al-Kutub, 2000, hlm. 73.

${ }^{20}$ Ahmad Tafsir, Ilmu Pendidikan Islami, Bandung: Rosdakarya, hlm.107
} 
membentuk anak didik melalui faktor eksternal, namun ia juga meciptakan kondisi dan situasi yang sesuai agar potensi bawaan anak dapat tersalurkan.

Dalam hal ini para pemikir muslim mempunyai penekanan yang berbeda. Hal itu karena didasarkan kepada ajaran Islam yang menyeluruh (syumul) dalam melihat realitas. Islam menganut konsep keseimbangan, konsep ilmu yang jelas dapat mengantarkan kepada keyakinan, dan konsep kemanusiaan. Dibawah ini akan diuraikan beberapa pandangan pemikir muslim yang berijak pada pandangan umum diatas:

Misalnya pandangan Abduh hidup pada masa kemunduran umat Islam yang sedang menghadapi problem dokotomisasi ilmu pengetahuan. Oleh karena itu pendidikan, menurutnya bertujuan untuk melahirkan muslim kamil yaitu yang integrate antara wawasan keagamaan yang mengakar dan wawasan umum yang luas. Atau dalam bahasa lain, dapat berpikir kritis, komperhensif, progresif, dan seimbang.

Fadlur Rahman melihat beberapa problem yang dihadapi umat berupa problem: ideologis, dualisme sistem pendidikan, bahasa, dan metodologi. Berangkat dari problem diatas, Rahman merumuskan tujuan pendidikan untuk mengembangkan manusia sedemikian rupa. Berbeda dengan Abduh, Rahman menitikberatkan pada penggunaan ilmu pengetahuan yang diperoleh untuk kemanfaatan manusia. Sedangkan Abduh lebih menekankan pentingnya pemahaman terhadap pengetahuan.

Dari sudut padangan berbeda, Al-Attas mengemukakan bahwa persoalan manusia modern adalah kerancuan ilmu pengetahuan (confussion of knowledge), dewesternisasi, yang mengakibatkan krisis dan kekosongan adab (the loss of adab). Al-Attas melihat dab sebagai persoalan inti manusia modern. Maka oleh karena itu, Naquib Al-Attas yang menggariskan tujuan pendidikan untuk mencetak manusia beradab.

\section{Kurikulum Pendidikan}

Kurikulum pendidikan Islam harus komperhensif meliputi aspek jasmani, akal dan ruhani. Dapat mengembangkan potensi yang melekat 
(nativsime) dan di usahakan (empirisme). Memenuhi kebutuhan manusia di dunia dan akhirat.

Berbeda dengan Dewey yang menjadikan kebutuhan masyarakat sebagai dasar pijakannya, maka kurikulum harus berorientasi untuk memenuhi kebutuhan masyarakat. Ia menggariskan beberapa syarat yang harus ada dalam kurikulum: 1. Bahan ajar hendaknya konkret, benar-benar bergunan dan dibutuhkan masyarakat. 2. Pengetahuan yang diperoleh harus disusun secara sistematis sehingga dapat diberakukan progress. 3. Bahan pelajaran tidak hanya dapat diambil dari buku namun juga pengalaman. 4. Harus berisi kemungkinan yang mendorong untuk giat dan berbuat. 5. Harus dapat memberikan rangsangan untuk bereksperimen. 6. Bahan pelajaran diberikan dengan menyertakan studi masalah.

Bagi aliran Nativisme, kurikulum harus bertumpu kepada bakat bawaan anak yang bersifat kodrati. Ia melihat kurikulum pendidikan harus dapat memunculkan potensi bawaan anak yang dijelaskan oleh teori disiplin mental, didalamnya terdapat: teistik, humanistik, naturalisme, dan apersepsi.

Sedangkan bagi William Stern melalui konvergensinya, kurikulum pendidikan harus dirumuskan dengan memadukan kurikulum pada aliran empirisme dan nativisme.

Hal ini berbeda dengan pemikir Islam, implikasi dari konsep integrasi versi Abduh untuk menyelesaikan persoalan dikotomi diatas, maka dalam rumusan kurikulum pendidikan Islamnya Abduh memasukkan materi filsafat, logika, dan ilmu pengetahuan modern setelah ilmu akidah dan syariat.

Dari uraian Rahman mengenai problem yang dihadapi pendidikan Islam yang meliputi problem ideologis, dualisme sistem pendidikan, bahasa, dan metodologi, maka kurikulum pendidikan Islam harus diarahkan untuk dapat memecahkan problem-problem diatas. Karena menurut Rahman, muslim harus dapat bersaing di zaman modern ini. Maka diperlukan pengetahuan modern melalui pembelajaran prinsip dasar ilmu sosial, worldview sain modern dan 
pengantar sejarah dunia, ilmu humaniora modern harus dimasukan dalam silabi diintegrasikan dengan ilmu agama.

Dalam kurikulum Al-Attas menekankan pembagian disiplim ilmu menjadi fardlu 'ain dan kifayah. Pembagian diatas tidak bersifat dikotomis namun penekanan skala prioritas agar tidak membuat anak didik bingung dan dapat menyelesaikan krisis adab.

\section{Metode dalam Proses Belajar Mengajar}

Metode pendidikan harus dibangun atas daya akal yang diterima oleh fitrah sehingga dapat memunculkan tauhid dan menyeleraskan dengan semua unsur kehidupan. ${ }^{21}$

Atau dalam bahasa lain ia harus dapat: a) Berbicara kepada akal dan hati secara bersamaan; b) Mengugah perasaan dan pikiran: c) Membangunkan emosi jiwa dan kekuatan intelegensi. ${ }^{22}$

Dari sudut pandang holistik, dapat dijelaskan bahwa seluruh representasi tradisi Islam telah mengaplikasikan berbagai metode dalam setiap penelitian yang mereka lakukan seperti, religius dan ilmiah, empiris dan rasional, deduktif dan induktif, subjektif dan objektif tapa menjadikan salah satu metode lebih dominan dari yang lain. Pendapat ini berbeda dengan Muhammad Iqbal yang menyatakan bahwa kemajuan Islam berasal dari cara berpikir induktif. ${ }^{23}$

Barat misalnya Dewey berpandangan bahwa, proses belajar harus aktif dan pprogresif tidak pasif dan stagnan didasarkan kepada pengalaman efektif dengan menggunakan daya pikir reflektif. Hal ini diuraikannya dengan: 1. Merasakan adanya keragukan dan kebingungan. 2. Mengadakan interpretasi tentative (merumuskan hipotesis). 3. Mengadakan penelitian atau pengumpulan data yang cermat. 4. Memperoleh hasil pembuktian.

\footnotetext{
${ }^{21}$ Al-Nahlawy, Ushul Al-Tarbiyah, hlm. 76

${ }^{22}$ Muhammad Al-Ghazali, 'Aqidatu Al-Muslim, Mesir: Dar Nahdlah Mishr, 2005, cet-ke. V, hlm.3

${ }^{23}$ Wan Mohd Daud, Filsafat dan Praktik Pendidikan Islam Menurut Syed Naquib Al-Attas, Bandung: Mizan, cet ke-I, 2003, hm.293
} 
Proses belajar dalam aliran nativisme bertumpu pada potensi kodrati anak. Pengetahuan mengenai potensi anak akan sangat menentukan. Maka diperlukan pemahaman mengenai teori disiplin mental diatas. Aliran ini bersikap pesimis terhadap peran pendidikan.

Dalam proses belajar-mengajar versi Abduh diharuskan peralihan paradigma dari yang sebelumnya menggunakan hafalan beralih ke insight pendalaman dan rasional begitu juga melalui pembiasaan munadzarah dalam proses akan melahirkan daya kritis tidak taklid.

Proses belajar-mengajar bagi Rahman harus bersifat kreatif dan dinamis tidak kaku. Dan bagi Al-Attas proses belajar mengajar harus berpijak pada adab.

\section{Kompetensi Guru}

Menguasai materi keislaman secara komperhensif. 2. Penguasaan strategi (mencakup pendekatan, metode, dan teknik). 3. Penguasaan ilmu dan wawasan kependidikan. 4. Memiliki prinsip-prinsip dalam menasfsirkan hasil penelitian pendidikan. 5. Peka terhadap informasi.

Kompetensi yang dimiliki Nabi: bekal kepribadian (personaliti) yang unggul, peduli terhadap masalah sosial, semangat dan ketajaman dalam iqra' mampu mempertahankan dan mengembangkan kulalitas iman, amal saleh, berjuang, dan bekerjasama menegakkan kebenaran, dan kesabaran. ringkasnya pendidika harus mempunyai kompetensi personal religious, sosial- religius, dan professional-religius. 24

\section{Penutup}

Berdasarkan uraian singkat mengenai Filsafat Islam dan Barat mengenai manusia dan kaitannya dengan konsep pendidikan, dapat disimpulkan bahwa, manusia dalam pandangan Islam dan Barat sangat berbeda. Islam memandang manusia satu kesatuan yang tak terpisahkan. Ia bukan hanya jasad tanpa ruh, seperti pendapat filsafat materialisme ataupun ruh tanpa jasad seperti pandangan aliran spritulaisme. Sebagaimana ia bukan hanya akal sekedar

\footnotetext{
${ }^{24}$ Abdul Mujib dan Jusuf Mudzakkir, hlm. 94-95
} 
sedang jasad hanyalah produk dari akal (nitaj 'aql) seperti pendapat filosof yang berpandang thinking being atau yag dikenal cogito ergo sum oleh bapak Filsafat Modern. ${ }^{25}$ Islam memandang manusia seutuhnya, jasad dan ruh tak terpisah, menyatu dan seirama, akal, ruh dan jasadnya membentuk segitiga sama sisi yang harus sama-sama di isi, ia adalahh makhluk yang bersifat individu (fardiyah) sekaligus berkarakter sosial (ijtima'i), itu semua karena ia ciptaan Allah yang sempurna (ahsani taqwim).

Sedangkan dalam pandangan Barat, manusia dirusmukan dan dibatasi berdasarkan penilaian masing-masing pakar dan disiplin keilmuan masingmasing. Karena manusia dalam terminologi psikolog tidak sama dengan terminologi, sosiolog maupun filosof. Lebih dari itu perbedaan tersebut bukan hanya dalam ranah syakli (kulit luar) namun juga pada esensi (hakikat) manusia. Terlihat jelas mulai dari yang memaknai manusia hanya sebatas materi, berunsurkan daging dan tulang, tidak ubahnya seperti robot, atau ia adalah makhluk yang juga berunsurkan akal. Aliran filsafat materialisme, empirisme, rasionalisme, maupun spritualisme, masing-masing menekankan maksudnya yang berbeda dari yang lain. Hal itu disebabkan karena pengetahuan Barat didasarkan kepada daya nalar (ratio) dan hal lain yang bersifat experimental (tajribi) sehingga menjadikan pemahaman mengenai manusia tidak sejajar, dan berdampak parsial. Jikapun ada aliran yang berusaha menjembatani problem dikotomis tersebut seperti teori konvergensi atau yang dikenal sekarang dengan ESQ (emotional, spiritual, question) namun tetap saja ada missing link, mata rantai yang hilang dengan sang Pencipta Yang Maha Tahu (Al-“Aql Al-Fa'âl) mengenai makhluk-Nya bernama manusia. Wallahu A'lam.

\footnotetext{
${ }^{25}$ Hasan Ibrahim Abdul ‘Al, Muqaddimah fi al-Tarbiyah ..., hlm.31
} 


\section{DAFTAR PUSTAKA}

Al-Bûthî, Muhammad Sa'id Ramadlân, "Kubra Al-Yaqiniyyat Al-Kauniyah: Wujûu Al-Khâliq WaWadzifât Al-Maklûq", 1997 Al-Islâm Malâdza Kulli Al-Mujtama'ât A-Insâniyah, Limâdzâ wa Kaifa?, Damasus : Dar Al-Fikr, 1413 H/ 1993 M

Al-Kîlanî, Madjid 'Irsan, Al-Fikr Al-Tarbawi 'Inda Ibn Taimiyah, Madinah Munawarah: Maktabah Dar al-Turats, 1986 M/ 1407 H

Al-Hâzimî, Khâlid bin Hâmid, Ushul al-Tarbiyah al-Islamiyah, Riyadl: Dar 'Alam Al-Kutub, 2000.

Al-Nahlawî, Abdurrahman, Ushul Al-Tarbiyah Wa Asalîbuha fi Al-Baiti Wa AlMadrasah Wa Al-Mujtama', Damaskus: Dar Al-fikr, 2008 M/ 1429 H.

Abdul 'Al, Hasan Ibrahim, Al-Muqaddimah fi Al-Falsafah Al-Tarbiyah AlIslamiyah, Riyadl: Dar 'Alam al-Kutub, 1985

Al-Ghazâlî, Muhammad, 'Aqidatu Al-Muslim, Mesir: Dar Nahdlah Mishr, 2005

Al-Syaibanî, Omar Muhammad, Filsafat Pendidikan Islam, Jakarta: Bulan Bintang, tnp. Thun

Majid, Abdul dan Jusuf Mudzakkir, Ilmu Pendidikan Islam, Jakarta: Kencana, 2008

Nata, Abudin, Pemikiran Pendidikan Islam dan Barat, Jakarta: PT Grafindo Persada, 2012

Adi, Rianto, Metodologi Penelitian Sosial dan Hukum, Jakarta: Granit, 2004

Shihab, Quraish, Wawasan Al-Qur'an, Bandung: Penerbit Mizan, cetakan VII, 1996

Tafsir, Ahmad, Filsafat Pendidikan Islam, Bandung: Rosdakarya, 2008 Ilmu Pendidikan Islami, Bandung: Rosdakarya, 2008

Tim Lokakarya, Islam dan Pendidikan Nasional, Jakarta: Lembaga Penelitian IAIN Syarif Hidayatullah, 1983.

Wan Daud, Wan Mohd Noor, Filsafat dan Praktik Pendidikan Islam Menurut Syed Naquib Al-Attas, Bandung: Mizan, cet ke-I, 2003 